\title{
Hyperlipidemia in Children with Chronic Renal Insufficiency
}

\author{
ZOE L. PAPADOPOULOU, ${ }^{(44)}$ PAUl SANDLER, LETICIA U. TINA, PEDRO A. JOSE, \\ AND PHILIP L. CALCAGNO \\ Department of Pediatrics and the Division of Pediatric Nephrology, Georgetown University School of Medicine, and \\ Georgetown University Medical Center, Washington, D. C., USA
}

\begin{abstract}
Summary
Total serum cholesterol, phospholipids, and triglyceride levels, lipoprotein fractionation, and plasma parathormone levels were measured in a group of 31 nonnephrotic children with various levels of renal function and on hemodialysis. Group A served as controls and consisted of eight healthy children with glomerular filtration rate (GFR) greater than $110 \mathrm{ml} / \mathrm{min} / 1.73 \mathrm{~m}^{2}$. Group B consisted of six children with GFR of 60 to $95 \mathrm{ml} / \mathrm{min} / 1.73 \mathrm{~m}^{2}$. Group C consisted of nine children with GFR of 10 to $40 \mathrm{ml} / \mathrm{min} /$ $1.73 \mathrm{~m}^{2}$, and group $D$ consisted of eight children on maintenance hemodialysis with GFR of 0 to $5 \mathrm{ml} / \mathrm{min} / 1.73 \mathrm{~m}^{2}$. Among the groups, there were no significant differences in total serum cholesterol and phospholipid levels. A significant $(P<0.05)$ increase in triglyceride levels was observed in patient groups $C$ and $D$.

Lipoprotein fractionation revealed a significant increase $(P<$ 0.05 ) in the pre-beta lipoprotein levels (very low density lipoproteins) in patients in group $D$ with $63 \%$ of these patients demonstrating a type IV lipoprotein pattern. There were no significant differences observed in the beta lipoproteins (low-density lipoproteins). However, the alpha lipoproteins (high-density lipoproteins) decreased significantly $(P<0.05)$ in patients whose GFR was below $40 \mathrm{ml} / \mathrm{min} / 1.73 \mathrm{~m}^{2}$ (group $C$ ) as well as patients in group $D$.

Absolute plasma parathormone levels did not significantly correlate with serum triglyceride levels and remained normal until after the onset of hemodialysis when they increased significantly in all patients.
\end{abstract}

\section{Speculation}

Evidence has been accumulating over the past few years that chronic hemodialysis and renal transplant adult patients have shortened survival because of accelerated atherosclerotic cardiovascular disease for which hyperlipidemia could be one of several etiologic factors. Similar epidemiologic studies have not been performed in children. We have demonstrated for the first time in children that alterations in serum triglycerides and alpha lipoproteins (high-density lipoproteins) occur early in chronic renal insufficiency and before the onset of uremia when the glomerular filtration rate falls below $40 \mathrm{ml} / \mathrm{min} / 1.73 \mathrm{~m}^{2}$. These lipid abnormalities become further aggravated with the onset of hemodialysis. If pediatric renal transplant patients show similar lipid abnormalities, then the potential for cardiovascular complications will be of importance in the early medical management of these children.

Alterations in lipid metabolism in adult uremic patients were initially described when lactescent serum was observed in patients with chronic renal disease (2). More recent studies have demonstrated that hyperlipidemia associated with elevated triglyceride levels is a frequent finding in adults with end-stage renal disease as well as in those patients undergoing chronic hemodialysis $(3,6$, $7,19,29,39)$.
Various types of lipoprotein abnormalities (example, high-density lipoproteins) are well recognized as predictors of atherosclerotic disease (23), and recent evidence highlights a high rate of mortality from arteriosclerotic complications in adults on longterm hemodialysis with persistent hyperlipidemia $(4,6,11,27,28$, 30). Furthermore, transplantation does not significantly reduce the incidence of cardiovascular complications because hyperlipidemia has been shown to exist after renal transplantation $(8,12$, $18,22,30$ ).

Children have been considered as acceptable candidates for dialysis and transplantation for the past few years, but there have been no systematic studies as to the occurrence of hyperlipidemia in this young age group. The objective of the present study was to investigate the lipid profile in a group of nonnephrotic children with various degrees of renal insufficiency and while undergoing chronic hemodialysis. In addition, absolute parathyroid hormone (PTH) levels were measured in patient groups B, C, and D because it has been postulated that in uremia the increased levels of PTH may be associated with an increased rate of hepatic gluconeogenesis (17) and thus possibly contribute to the pathogenesis of hyperlipidemia.

\section{MATERIALS AND METHODS}

Total serum cholesterol, phospholipids, and triglyceride levels, and lipoprotein fractionation were measured in 31 nonnephrotic children. Patients were assigned to groups according to various levels of renal function. Group A served as controls and consisted of eight healthy children with glomerular filtration rate (GFR) greater than $110 \mathrm{ml} / \mathrm{min} / 1.73 \mathrm{~m}^{2}$. Group B consisted of six children with GFR of $60-95 \mathrm{ml} / \mathrm{min} / 1.73 \mathrm{~m}^{2}$. Group C consisted of nine children with GFR of 10 to $40 \mathrm{ml} / \mathrm{min} / 1.73 \mathrm{~m}^{2}$, and group $D$ consisted of eight children on maintenance hemodialysis with GFR of 0 to $5 \mathrm{ml} / \mathrm{min} / 1.73 \mathrm{~m}^{2}$. None of the patients in groups $\mathrm{A}$, $\mathrm{B}$, and $\mathrm{C}$ were known to have pre-existing diabetes mellitus, hyperlipidemia, or heart disease. The age, sex, GFR and underlying renal disease in the four groups of patients are depicted in Table 1 . The controls ranged in age from 4 to 18 years. Three were females, and five were males. In group $D$, patients 24,25 , and 26 had the nephrotic syndrome but had been anephric for 12 to 17 months before the study. Their serum protein electrophoresis was within normal range. Duration of hemodialysis treatment was between 1 to 36 months (13 months on the average). Dialysis was performed for $5 \mathrm{hr}$ three times per wk using either Gambro Optima or Cordis Dow dialyzers. The dialysate contained $200 \mathrm{mg}$ of dextrose per dl. All dialysis patients were in a stable state receiving approximately the same renal diet calculated on a weight basis to supply the recommended daily caloric allowance with the protein intake ranging between 1.5 and $2.5 \mathrm{~g} / \mathrm{kg}$ depending on the age of the child. Children in groups $A, B$, and $C$ received a regular diet. Amphogel was administered to patients in groups $C$ and D whose serum phosphorus level exceeded $5.5 \mathrm{mg} / \mathrm{dl}$. 
Table 1. The age, sex, GFR, ${ }^{1}$ and underlying renal disease in the four groups of patients

\begin{tabular}{lcccc}
\hline Patient groups and case nos. & Age (years) & Race/sex & $\begin{array}{c}\text { GFR }(\mathrm{ml} / \mathrm{min} / \\
\left.1.73 \mathrm{~m}^{2}\right)\end{array}$ \\
\hline Group A (GFR 110-134 ml/min/1.73 $\mathbf{m}^{2}$ ) & & & & \\
1 & 12 & W/M & 126 & None \\
2 & 11 & W/M & 118 & None \\
3 & 7 & W/M & 124 & None \\
4 & 6 & B/F & 116 & None \\
5 & 7 & B/M & 114 & None \\
6 & 8 & B/M & 120 & None \\
7 & 4 & W/F & 110 & None \\
8 & 18 & W/F & 134 & None \\
Mean & 9.1 & & &
\end{tabular}

Group B (GFR 60-95 ml/min/1.73 $\mathrm{m}^{2}$ )

$\begin{array}{lclll}9 & 12 & \text { W/M } & 95 & \text { Dysplastic kidneys } \\ 10 & 11 & \text { W/F } & 92 & \text { Recurrent UTI } \\ 11 & 17 & \text { W/F } & 74 & \text { Bilateral hydronephrosis } \\ 12 & 18 & \text { B/M } & 71 & \text { Hypertension } \\ 13 & 6 & \text { W/M } & 69 & \text { Polycystic kidneys } \\ 14 & 9 & \text { W/M } & 66 & \text { Bilateral hydronephrosis } \\ \text { Mean } & 12.2 & & \end{array}$

Group C (GFR $\left.10-40 \mathrm{ml} / \mathrm{min} / 1.73 \mathrm{~m}^{2}\right)$

15
16
17
18
19
20
21
22
23
Mean

$\begin{array}{rlll}3 & \text { B/M } & 38 & \text { Interstitial nephritis } \\ 18 & \text { B/M } & 33 & \text { Chronic glomerulonephritis } \\ 11 & \text { W/F } & 33 & \text { Chronic pyelonephritis } \\ 17 & \text { B/M } & 29 & \text { Bilateral hydronephrosis } \\ 14 & \text { W/F } & 27 & \text { Chronic pyelonephritis } \\ 14 & \text { B/F } & 25 & \text { Dysplastic. kidneys } \\ 4 & \text { W/M } & 18 & \text { Bilateral hydronephrosis } \\ 8 & \text { W/M } & 17 & \text { Dysplastic kidneys } \\ 12 & \text { W/M } & 10 & \text { Bilateral hydronephrosis }\end{array}$

Group D (Hemodialysis)

\begin{tabular}{|c|c|c|c|c|}
\hline 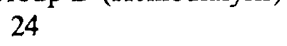 & 15 & $\mathrm{~B} / \mathrm{F}$ & Anephric & Membranoproliferative GN \\
\hline 25 & 14 & $\mathrm{~B} / \mathrm{M}$ & Anephric & Membranoproliferative GN \\
\hline 26 & 16 & $\mathrm{~B} / \mathrm{F}$ & Anephric & Focal segmental glomerulosclerosis \\
\hline 27 & 17 & $\mathrm{~B} / \mathrm{F}$ & Anephric & Dysplastic kidneys \\
\hline 28 & 15 & $\mathbf{W} / \mathbf{M}$ & 5 & Hereditary nephritis \\
\hline 29 & 12 & $\mathbf{W} / \mathbf{M}$ & 5 & Bilateral hydronephrosis \\
\hline 30 & 8 & $\mathbf{W} / \mathbf{M}$ & 3 & Dysplastic kidneys \\
\hline 31 & 10 & $\mathrm{~W} / \mathrm{M}$ & 2 & Cystinosis \\
\hline Mean & 13.4 & & & \\
\hline
\end{tabular}

${ }^{1}$ GFR: Actual glomerular filtration rate as estimated by the endogenous clearance of creatinine.

Venous blood samples were obtained in the recumbent position following a 12- to 14-hr fast. For patients in group D, blood samples were collected before the beginning of hemodialysis and approximately $48 \mathrm{hr}$ after the last dialysis treatment. Lipoprotein fractionation of the serum was accomplished by means of the Beckman microzone electrophoresis technique using Agarose gel (34). Serum triglycerides and phospholipids were measured by the method of Kessler (25), and total serum cholesterol was measured by the method of Wybenga et al. (40). Changes in the serum lipids were statistically compared among the four groups of patients and were further compared with published reports of 95th percentiles for plasma lipids and lipoproteins in children $(16,26,33,38)$. PTH levels were measured by radioimmunoassay using an antiserum specific for the carboxy-terminal region (21). PTH levels were plotted as a function of the serum calcium level (21). Glomerular filtration rate was estimated by the endogenous clearance of creatinine. Creatinine was determined by the method of Hare (20).

All statistical calculations and correlations were determined by employing the Student $t$ test.

\section{RESULTS}

The results (mean \pm standard error) of the total serum cholesterol, phospholipids, and triglycerides for the four groups of patients are summarized in Table 2 together with the $P$ values as compared to controls. Among the groups, there were no significant differences in total serum cholesterol and phospholipid levels. There was, however, a significant increase in the triglyceride levels observed in patients with GFR less than $40 \mathrm{ml} / \mathrm{min} / 1.73 \mathrm{~m}^{2}$ (group C) as well as in patients in group D. The values obtained in these groups were significantly higher $(P<0.05)$ than in controls and group B patients who had only a mild reduction of the GFR. Mean triglyceride concentration was $107 \pm 14 \mathrm{mg} / \mathrm{dl}$ (range, 77 to $209 \mathrm{mg} / \mathrm{dl}$ ) in patients in group C and $171 \pm 27 \mathrm{mg}$ / dl (range, 105 to $292 \mathrm{mg} / \mathrm{dl}$ ) in patients in group D as compared to control values of $68 \pm 8 \mathrm{mg} / \mathrm{dl}$ (range, 41 to $101 \mathrm{mg} / \mathrm{dl}$ ). Furthermore, patients on hemodialysis (group D) had even significantly higher triglyceride levels than did patients in group $\mathrm{C}$ $(P<0.05)$. A threshold effect of GFR on hypertriglyceridemia 
could not be ascertained because there were no patients whose GFR ranged between 40 and $60 \mathrm{ml} / \mathrm{min} / 1.73 \mathrm{~m}^{2}$. A regression analysis using the least square method showed a correlation coefficient between GFR (independent variable) and serum triglyceride levels (dependent variable) to be 0.60 with a $P$ value $<$ 0.002 . Clearly, the serum triglyceride levels became significantly elevated once the GFR decreased below $40 \mathrm{ml} / \mathrm{min} / 1.73 \mathrm{~m}^{2}$.

The lipoprotein pattern in the patient groups is shown in Table 3 together with the $P$ values as compared to controls. The prebeta lipoprotein levels [very low density lipoproteins (VLDL)] were significantly elevated $(P<0.05)$ only in group $D$. Five of eight children in this group (63\%) had the type IV lipoprotein

Table 2. Total serum cholesterol, phospholipids, and triglycerides in the four groups of patients in order of decreasing GFR

\begin{tabular}{lccc}
\hline \multicolumn{2}{c}{$\begin{array}{c}\text { Total serum } \\
\text { cholesterol } \\
\text { Patient groups and case nos. }\end{array}$} & $\begin{array}{c}\text { Phospholip- } \\
\text { ids }(\mathrm{mg} / \mathrm{dl})\end{array}$ & $\begin{array}{c}\text { Triglycerides } \\
(\mathrm{mg} / \mathrm{dl})\end{array}$ \\
\hline $\begin{array}{l}\text { Group A (Controls, GFR } 110- \\
\left.\text { 134 ml/min/1.73 m }{ }^{3}\right)\end{array}$ & & & \\
& & & \\
1 & 214 & 233 & 78 \\
2 & 189 & 200 & 101 \\
3 & & & \\
4 & 137 & 159 & 62 \\
5 & 132 & 151 & 68 \\
6 & 147 & 180 & 41 \\
7 & & & \\
8 & 180 & 171 & 57 \\
Mean \pm S.E. & $167 \pm 13$ & $182 \pm 12$ & $68 \pm 8$
\end{tabular}

Group B (GFR 60-95 ml/ $\min / 1.73 \mathrm{~m}^{2}$ )

$\begin{array}{lccc}9 & 171 & 192 & 68 \\ 10 & 162 & 168 & 60 \\ 11 & 260 & 258 & 45 \\ 12 & 168 & 208 & 78 \\ 13 & 149 & 171 & 20 \\ 14 & 191 & 261 & 62 \\ \text { Mean } \pm \text { S.E. } & 184 \pm 16 & 210 \pm 17 & 56 \pm 8\end{array}$

Group C (GFR $10-40 \mathrm{ml} /$ $\min / 1.73 \mathrm{~m}^{2}$ )

$\begin{array}{lllr}15 & 206 & 272 & 77 \\ 16 & 156 & & 105 \\ 17 & 204 & 229 & 94 \\ 18 & 179 & & 86 \\ 19 & 125 & 145 & 209 \\ 20 & 246 & 330 & 83 \\ 21 & 209 & & 120 \\ 22 & 182 & & 113 \\ 23 & 266 & & 79 \\ \text { Mean } \pm \text { S.E. } & 197 \pm 14 & 244 \pm 39 & 107 \pm 14^{1}\end{array}$

Group D (Hemodialysis)

\begin{tabular}{lcll}
24 & 167 & 178 & 154 \\
25 & 174 & 188 & 105 \\
26 & 172 & 196 & 105 \\
27 & 251 & 332 & 120 \\
28 & 151 & 254 & 209 \\
29 & 193 & 275 & 115 \\
30 & 215 & 238 & 292 \\
31 & 255 & 303 & 264 \\
Mean \pm S.E. & $197 \pm 14$ & $246 \pm 20$ & $171 \pm 27^{1,2}$ \\
\hline
\end{tabular}

\footnotetext{
${ }^{1} P<0.05$ as compared to controls.
}

${ }^{2} P<0.05$ as compared to group $\mathrm{C}$.
Table 3. The lipoprotein pattern in the four patient groups according to decreasing $G F R^{1}$

\begin{tabular}{lccc}
\hline $\begin{array}{c}\text { Patient groups and } \\
\text { case nos. }\end{array}$ & $\begin{array}{c}\text { Pre-beta lipo- } \\
\text { proteins (\%) } \\
\text { (VLDL) }\end{array}$ & $\begin{array}{c}\text { Beta lipo- } \\
\text { proteins (\%) } \\
\text { (LDL) }\end{array}$ & $\begin{array}{c}\text { Alpha lipo- } \\
\text { proteins (\%) } \\
\text { (HDL) }\end{array}$ \\
\hline $\begin{array}{l}\text { Group A (Controls, GFR } \\
\text { 110-134 ml/min/1.73 }\end{array}$ & & & \\
$\mathrm{m}^{2}$ ) & & & \\
& & & \\
1 & 5.5 & 44.8 & 48.8 \\
2 & 19.2 & 50.7 & 28.6 \\
3 & 11.0 & 469 & 35.2 \\
4 & 13.6 & 46.4 & 39.7 \\
5 & 11.7 & 50.9 & 34.4 \\
6 & 13.2 & 43.0 & 43.8 \\
7 & 7.9 & 51.2 & 39.8 \\
8 & 5.4 & 43.7 & 50.9 \\
Mean \pm S.E. & $10.9 \pm 1.6$ & $47.2 \pm 1.2$ & $40.1 \pm 2.7$
\end{tabular}

Group B (GFR 60-95 ml/ $\left.\min / 1.73 \mathrm{~m}^{2}\right)$

$\begin{array}{lcll}9 & 15.2 & 47.7 & 36.1 \\ 10 & 17.3 & 47.0 & 35.7 \\ 11 & 17.4 & 41.5 & 41.0 \\ 12 & 9.7 & 54.0 & 35.5 \\ 13 & 3.6 & 48.0 & 48.4 \\ 14 & 5.6 & 60.0 & 34.4 \\ \text { Mean } \pm \text { S.E. } & 11.5 \pm 2.5 & 49.7 \pm 2.6 & 38.5 \pm 2.1\end{array}$

Group C (GFR $10-40 \mathrm{ml} /$ $\left.\min / 1.73 \mathrm{~m}^{2}\right)$

$\begin{array}{lrll}15 & 17.9 & 64.5 & 10.9 \\ 16 & 20.8 & 45.5 & 31.4 \\ 17 & 14.8 & 53.7 & 25.5 \\ 18 & 19.3 & 46.9 & 31.9 \\ 19 & 28.2 & 37.2 & 34.7 \\ 20 & 4.1 & 54.1 & 33.3 \\ 21 & 6.5 & 70.0 & 23.0 \\ 22 & 23.1 & 54.6 & 16.0 \\ 23 & 4.5 & 62.0 & 32.5 \\ \text { Mean } \pm \text { S.E. } & 15.5 \pm 2.9 & 54.3 \pm 3.4 & 26.6 \pm 2.8^{2}\end{array}$

Group D (Hemodialysis)

\begin{tabular}{llll}
24 & 33.3 & 46.0 & 20.8 \\
25 & 31.8 & 41.7 & 31.5 \\
26 & 20.7 & 49.2 & 28.4 \\
27 & 19.3 & 25.7 & \\
28 & 29.0 & 38.9 & 32.2 \\
29 & 12.1 & 53.2 & 34.7 \\
30 & 20.5 & 52.5 & 27.0 \\
31 & 18.4 & 68.7 & 12.8 \\
Mean \pm S.E. & $23.1 \pm 2.6^{2}$ & $46.9 \pm 4.4$ & $26.8 \pm 2.9^{2}$ \\
\hline
\end{tabular}

${ }^{1}$ The pre-beta, beta and alpha lipoproteins are depicted as the percentage of the total lipoproteins.

${ }^{2} P<0.05$ as compared to controls.

phenotype, and one had the type II $b$ pattern. In patients in group C, with GFR below $40 \mathrm{ml} / \mathrm{min} / 1.73 \mathrm{~m}^{2}$, although the mean level of the pre-beta lipoproteins was not significantly elevated from control values; nevertheless in three of these children (33\%) the actual levels were more than two standard deviations greater than were controls demonstrating the type IV lipoprotein phenotype. There were no significant differences observed in the beta lipoproteins [low-density lipoproteins (LDL)]. However, the alpha lipoproteins [high-density lipoproteins (HDL)] decreased significantly $(P<0.05)$ in patients with GFR below $40 \mathrm{ml} / \mathrm{min} / 1.73 \mathrm{~m}^{2}$ (group $\mathrm{C}$ ) as well as in patients in group D. The correlation 
coefficient with alpha lipoproteins as the dependent variable and the GFR as the independent variable was 0.5 with a $P$ value $<$ 0.02 . As in the case of serum triglycerides, this linear regression analysis was limited by the absence of GFR values between 40 and $60 \mathrm{ml} / \mathrm{min} / 1.73 \mathrm{~m}^{2}$. It is clear, however, that once the GFR is below $40 \mathrm{ml} / \mathrm{min} / 1.73 \mathrm{~m}^{2}$ the alpha lipoprotein levels are significantly lower than are the levels noted when the GFR is greater than $60 \mathrm{ml} / \mathrm{min} / 1.73 \mathrm{~m}^{2}$.

Absolute PTH levels did not significantly correlate with serum triglyceride levels (correlation coefficient, 0.161). Serum PTH levels remained normal until after the onset of hemodialysis when they increased significantly in all patients.

\section{DISCUSSION}

The data demonstrate for the first time in children that alterations in serum triglycerides and alpha lipoproteins (HDL) occur early in chronic renal insufficiency and before the onset of uremia when the GFR falls below $40 \mathrm{ml} / \mathrm{min} / 1.73 \mathrm{~m}^{2}$. In these patients, the serum triglyceride levels become significantly elevated, and the alpha lipoproteins (HDL) markedly decreased as renal function deteriorates. These lipid abnormalities become further aggravated with the onset of hemodialysis. On the other hand, the serum total cholesterol, phospholipids, and beta lipoproteins (LDL) remain essentially unchanged.

Various published reports on plasma lipids and lipoprotein levels in normal children indicate that serum triglyceride levels tend to increase with age in all race-sex groups whereas serum cholesterol levels remain relatively constant until adolescence at which time they become slightly reduced $(16,26,33,38)$. The elevation of the serum triglyceride levels in our patient groups $\mathrm{C}$ and D were significantly higher than the median and the 95th percentile values reported for normal children of various age groups $(16,26,33)$. Furthermore, the changes in the serum triglyceride levels observed in patients with GFR below $40 \mathrm{ml} / \mathrm{min} /$ $1.73 \mathrm{~m}^{2}$ did not significantly correlate with age (correlation coefficient, 0.0). Similarly, the marked decrease in the alpha lipoproteins observed in patients in groups $\mathrm{C}$ and $\mathrm{D}$ did not significantly correlate with age (correlation coefficient, 0.3 with a $P$ value $<$ $0.16)$.

Elevated fasting triglyceride levels have been reported in adult uremic and dialyzed patients $(3,6,7,29,32,39)$. The lipid increment has been shown to be primarily in the pre-beta fraction (VLDL) which is triglyceride-rich $(9,13,22,24,32,36)$. Similarly, decreased levels in the alpha lipoproteins (HDL) have been described in adult uremic patients and are attributed to abnormally low levels of alpha lipoprotein cholesterol content $(5,22,32,36)$. Serum total cholesterol levels, on the other hand, have been shown to remain within normal range by all of these investigators. Thus, the nonnephrotic, chronically uremic state affects lipoprotein metabolism in such a way that triglyceride levels in the whole plasma as well as in the VLDL class (pre-beta lipoprotein) are elevated, cholesterol levels in whole plasma and in the LDL class (beta lipoproteins) are normal, and HDL levels (pre-beta lipoproteins) are markedly reduced. Furthermore, hyperlipidemia has been shown to persist after renal transplantation in children $(35,37)$ and adults $(8,12,18,22,27,30)$. Evidence has been accumulating over the past few years that chronic hemodialysis and renal transplant patients have shortened survival because of accelerated atherosclerotic cardiovascular disease $(28,30)$ for which hyperlipidemia could be one of several etiologic factors $(27,28,30)$. Similar epidemiologic studies have not been performed in children. Low levels of HDL (alpha lipoprotein) cholesterol has been shown to be also present in renal transplant adult patients (5) resulting in a high ratio of LDL to HDL cholesterol. It has been speculated by Bagdade et al. (5) that these lipid disturbances may play some role in the development of accelerated vascular disease in these patients. Whether such correlations indicate a causal relationship remains unclear however.

Few studies have been conducted in nonnephrotic patients with various degrees of renal function to document whether hyperlip- idemia occurs early in the course of renal insufficiency or whether it is a sole feature of end stage renal disease. Frank et al. (15), in a study of adult uremic patients on hemodialysis and in patients with normal to severely compromised renal function, found that hypertriglyceridemia developed as the creatinine clearance fell below $40 \mathrm{ml} / \mathrm{min}$. However, lipoprotein fractionation was not determined. Similar results have been reported by McCosh et al. (31). In our studies, although the triglyceride levels increased significantly when the GFR fell below $40 \mathrm{ml} / \mathrm{min} / 1.73 \mathrm{~m}^{2}$, the pre-beta lipoproteins (VLDL) did not significantly increase until after the onset of hemodialysis. However, three children in group C with GFRs of 33,27 , and $17 \mathrm{ml} / \mathrm{min} / 1.73 \mathrm{~m}^{2}$, respectively (patients 16, 19, and 22) did demonstrate a significant elevation of the pre-beta lipoproteins. The failure of patients in group $\mathrm{C}$ as a whole to demonstrate a significant elevation in the pre-beta lipoproteins cannot be explained as yet.

Dietary and hormonal factors did not appear to play a significant role in the pathogenesis of hyperlipidemia in our patients. Although a significant relationship between dietary carbohydrate and triglyceride concentration has been demonstrated by several investigators $(10,14,35)$, the alterations in lipid metabolism which were observed in patients in group $\mathrm{C}$ were unrelated to dietary factors since these children were in a stable nutritional state and receiving a normal diet. In addition, the diet in group $D$ patients was carefully regulated so that they all received an adequate caloric, protein, and carbohydrate intake. In addition, absolute PTH levels did not significantly correlate with serum triglyceride levels. A negative correlation was also demonstrated by Amend et al.(1) who studied adult uremic patients before and after parathyroidectomy and found no significant change in carbohydrate metabolism, in triglyceride levels, or in the incidence of type IV hyperlipidemia.

We have demonstrated that in children, the onset of hypertriglyceridemia and reduced levels of alpha lipoproteins (HDL) occur early in renal insufficiency when the GFR decreases below $40 \mathrm{ml} / \mathrm{min} / 1.73 \mathrm{~m}^{2}$. These lipid abnormalities, which are believed to accelerate altherosclerotic cardiovascular disease, become further aggravated with the onset of hemodialysis. If pediatric renal transplant patients show similar lipid abnormalities, then the potential for cardiovascular complications will be of importance in the early management of these children.

\section{REFERENCES AND NOTES}

1. Amend, W. C., Steinberg, S. M., Lowrie, E. G., et al.: The influence of serum calcium and parathyroid hormone upon glucose metabolism in uremia. J. Lab. Clin. Med., 86: 435, (1975).

2. Ash, B. J., and Bruger, M.: The cholesterol content of the plasma in chronic nephritis and retention uremia. Am. J. Med. Sci., 186: 670 (1933).

3. Bagdade, J. D.: Lipemia, a sequela of chronic renal failure and hemodialysis. Am. J. Clin. Nutr., 21: 426 (1968).

4. Bagdade, J. D.: Atherosclerosis in patients undergoing maintenance hemodialysis. Kidney Int., 7, (Suppl 3): S370 (1975).

5. Bagdade, J. D., and Albers, J. J.: Plasma high-density lipoprotein concentrations in chronic-hemodialysis and renal transplant patients. N. Engl. J. Med., 296: 1436 (1977)

6. Bagdade, J. D., Porte, D., Jr., and Bierman, E. L.: Hypertriglyceridemia: a metabolic consequence of chronic renal failure. N. Engl. J. Med., 279: 181 (1968).

7. Bagdade, J. D.: Uremic lipemia: an unrecognized abnormality in triglyceride production and removal. Arch. Intern. Med., 126: 875 (1970).

8. Braun, W. E., Manning, R. F., and Lewis, L. A.: Serum lipoprotein and lipid abnormalities in renal transplant recipients. Clin. Res., 21: 678 (1973).

9. Brons, M., Christensen, N. C., and Horder, M.: Hyperlipoproteinemia in patients with chronic renal failure. Acta Med. Scand., 192: 119 (1972).

10. Broyer, M., Tete, M. J., Laudat, M. H., et al: Plasma lipid abnormalities on chronic hemodialysis: relationship to dietary intake. Proc. Eur. Dial. Transpl. Assoc., 14: 385 (1976).

11. Brunner, F. P., Gurland, H. J., Harlen, H., et al: Combined report on regular dialysis and transplantation in Europe, II, 1971, Proc. Eur. Dial. Transpl. Assoc., 9: 3 (1972).

12. Casaretto, A. A., Marchioro, T. L., and Bagdade, J. D.: Hyperlipidemia following renal transplant. Trans. Am. Soc. Artif. Intern. Organs, 19: 154 (1973)

13. Cattran, D. C., Steiner, G., Fenton, S. S. A., et al: Hypertriglyceridemia in uremia and the use of triglyceride turnover to define pathogenesis. Trans. Am. Soc. Artif. Intern. Organs, 20: 148 (1974).

14. El-Bishti, M., Counahan, R., Jarret, R. J., et al.: Hyperlipidemia in children on regular hemodialysis. Arch. Dis. Child., 52: 932 (1977). 
15. Frank, W. M., Rao, T. K. S., Auram, J., et al:: Natural history of hyperlipoproteinemia in renal failure. Abst. Am. Soc. Nephr. 9th Annual Meeting, p. 12 (1976).

16. Frerichs, R. R., Srinivasan, S. E., Weber, L. S., et al.: Serum Cholesterol and triglyceride levels in 3,446 children from a bi-racial community. The Bogalusa Heart Study. Circulation, 54: 302 (1976).

17. Garber, A. J.: Abnormalities of carbohydrate metabolism in chronic uremia. Ninth Annual Contractor's Conference of the Artificial Kidney Program of the National Institute of Arthritis, Metabolism and Digestive Diseases, Bethesda, Md., p. 5 (1976).

18. Ghosh, P., Evans, D. B., and Tomlinson, S.: Hyperlipidemia after successful renal transplantation. Lancet, $1: 1054$ (1974)

19. Gutman, R. A., Uy, A., Shalhoub, R. J., et al.: Hypertriglyceridemia in chronic non-nephrotic renal failure. Am. J. Clin. Nutr., 26: 165 (1973).

20. Hare, R. S.: Endogenous creatinine in serum and urine. Proc. Soc. Exp. Biol. Med., 74: 148 (1950)

21. Hawker, C. D.: Parathyroid hormone: radioimmunoassay and clinical interpretation. Ann. Clin. Lab. Sci., 5: 383 (1975).

22. Ibels, L. S., Simons, L. A., King, J. O, et al.: Studies on the nature and causes of hyperlipidemia in uraemia, maintenance dialysis and renal transplantation. Q. J. Med., 44: 601 (1975).

23. Kannel, W. B., Castelli, W. P., Gordon, T., et al.: Serum cholesterol, lipoproteins, and the risk of coronary heart disease. The Framingham Study. Ann. Intern. Med., 74: 1 (1971).

24. Kaye, J. P., Moorehead, J. F., and Wills, M. R.: Plasma lipids in patients with chronic renal failure. Clin. Chim. Acta, 44: 301 (1973).

25. Kessler, G.: Automated techniques in lipid chemistry. Adv. Clin. Chem., 10: 45 (1967).

26. Kwiterovich, P. O., Chase, G. A., and Bachorik, P. S.: The Columbia population study. I. Plasma cholesterol and triglyceride levels. Johns Hopkins Med. J., 143: 32 (1978)

27. Lazarus, J. M., Lowrie, E. G., Hampers, C. L., et al:: Cardiovascular disease in uremic patients on hemodialysis. Kidney Int., 7 (Suppl. 2): SI67 (1975)

28. Lindner, A., Charra, B., Sherrard, D. J., et al.: Accelerated artherosclerosis in prolonged maintenance hemodialysis. N. Engl. J. Med., 290: 697 (1974).

29. Losowsky, M. S., and Kenward, D. W.: Lipid metabolism in acute and chronic renal failure. J. Lab. Clin. Med., 71: 736 (1968).

30. Lowrie, E. G., Lazarus, J. M., Mocelin, A. J., et al:: Survival of patients undergoing chronic hemodialysis and renal transplantation. N. Engl. J. Med., 288: 863 (1973).

31. McCosh, E. J., Solongi, K., Rivers, J. M., et al.: Hypertriglyceridemia in patients with chronic renal insufficiency. Am. J. Clin. Nutr., 28: 1036 (1975).

32. Mordasini, R., Frey, F., Flury, W., et al.: Selective deficiency of hepatic triglyceride lipase in uremic patients. N. Engl. J. Med., 297: 1362 (1977).

33. Morrison, J. A., deGroot, I., Edwards, B. K., et al.: Lipids and lipoproteins in 927 school children, ages 6 to 17 years. Pediatrics, 62: 990 (1978).

34. Noble, R. P.: Electrophoretic separation of plasma lipoproteins in agarose gel. $\mathbf{J}$. Lipid Res., 9: 693 (1968).

35. Pennisi, A. J., Heuser, E. T., Mickey, M. R., et al.: Hyperlipidemia in pediatric hemodialysis and renal transplant patients. Am. J. Dis. Child, 130: 957 (1976)

36. Rapoport, J., Aviram, M., Chaimovitz, C., et al.: Defective high-density lipoprotein composition in patients on chronic hemodialysis. N. Engl. J. Med., 299: 1326 (1978).

37. Soldanha, L. F., Hurst, K. S., Amend, W. J. C., et al: Hyperlipidemia after renal transplantation in children. Am. J. Dis. Child., 130: 951 (1976).

38. Srinivasan, S. R., Frerichs, R. R., Wegger, L. S., et al.: Serum lipoprotein profile in children from a bi-racial community. Circulation, 54: 309 (1976).

39. Tsaltas, T. T., and Friedman, E. A.: Plasma lipid studies of uremic patients during hemodialysis. Am. J. Clin. Nutr., 21: 430 (1968).

40. Wybenga, D. R., Pileggi, V. J., Dirstine, P. H., et al.: Direct manual determination of serum total cholesterol with a single stable reagent. Clin. Chem., 16: 980 (1970).

41. Informed consent was obtained from the parents of all children included in this study.

42. This paper was presented in part at the 87 th Annual Meeting of the American Pediatric Society and the Society for Pediatric Research, San Francisco, Ca. April 1977.

43. The authors are indebted to Gene Blaylock for his technical assistance and to Carolyn Patterson for preparation of the manuscript. The assistance of the nursing staff of the Pediatric Renal Hemodialysis Division is gratefully acknowledged.

44. Requests for reprints should be addressed to: Dr. Zoe Papadopoulou, Georgetown University Hospital, Department of Pediatrics, 3800 Reservoir Road, N.W., Washington, D. C. 20007 (USA).

45. Received for publication April 25, 1979.

46. Accepted for publication August 13, 1980. 